Int. Arch. Allergy 1962;20(Suppl. 1):I-III

\title{
Contents, Vol. 20, Supplement 1, 1962
}

\section{Index}

Introduction

1

Properties of $\mathrm{F}$

A. Inconsistencies in F Metabolism

I. Intake of Fluoride $\quad-\ldots 2$

Fluoride in Food $\quad$. 2

Fluoride in Air 5

Fluoride in Water

Fluoride in Drugs

Miscellaneous Sources

II. Absorption, Storage and Excretion

Uptake in Organs

9

Storage in the System

Excretion

B. Presence of $\mathrm{F}$ - in Tissue

In Bones 12

In Teeth 13

In Soft Tissue 13

Pathological Tissue $\quad 14$

In Aorta 16

C. Effect of $\mathrm{F}$ in Tissue

I. Pathological Physiology

Enzymes

17

CA++-P+ Metabolism

Thyroid

Teeth

Bones

20

Other Organs

II. Fluorosis

Incidence

Manifestations

Case Reports

Diagnosis of Fluorosis

Therapeutic Measures

Summary

References
22

22

22

25

29
2

6

7

7

9 